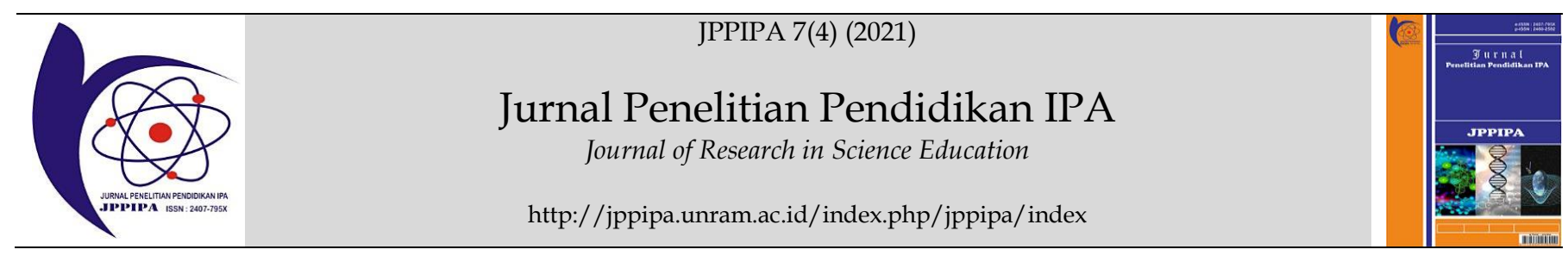

\title{
Application of Discovery Learning Model in Increasing Student Interest and Learning Outcomes
}

\author{
Rosnidar $^{1 *}$, Yusrizal ${ }^{2}$, Mustafa $^{2}$, Susanna $^{2}$ \\ 1Science Education Study Program, Postgraduate Program, Syiah Kuala University, Banda Aceh, Indonesia \\ ${ }^{2}$ Physics Education Study Program, Faculty of Teacher Training and Education, Syiah Kuala University, Banda Aceh, Indonesia
}

DOI: $\underline{10.29303 / \text { ippipa.v7i4.745 }}$

\section{Article Info}

Received: May 21st, 2021

Revised: September 1st, 2021

Accepted: September 26th, 2021

\begin{abstract}
This research aims to find out the application of discovery learning models in increasing students' interest and learning outcomes in harmonic vibrational materials in MAN 4 Aceh Besar. The method in this study is quasi-experimentation with the design of a pretest-posttest control group. The instruments used are questionnaires and problems. The results showed that the average $\mathrm{N}$-gain of student learning interest in the experimental class was 0.79 high category and control class 0.28 low category. The results of each experimental class indicator included a very positive category while the category control class was positive. Based on the results of the analysis of both classes, it can be concluded that the average interest in student learning in the experimental class is more increased than in the control class, especially on indicators of student engagement. The average $\mathrm{N}$ gain result of student learning outcomes in the experimental class obtained a score of 0.61 moderate categories, then in the control class obtained a score of 0.35 medium category. Based on the test results, the average of the two classes obtained significance scores of 0.000 $<0.05$, meaning that there was a difference in the average learning outcome of students in experimental classes and control classes. This proves that the discovery learning model's application can improve students' learning outcomes higher than the discovery learning model in the control class. This study concludes that the application of discovery learning models can increase students' interest and learning outcomes in harmonic vibrational materials in MAN 4 Aceh Besar.
\end{abstract}

Keywords: Discovery learning model; Learning interests; Learning Outcomes

Citation: Rosnidar, R., Yusrizal, Y., Mustafa, M., \& Susanna, S. (2021). Application of Discovery Learning Model in Increasing Student Interest and Learning Outcomes. Jurnal Penelitian Pendidikan IPA, 7(4), 542-548. doi:https:// doi.org/10.29303/jppipa.v7i4.745

\section{Introduction}

Education is one of the efforts that can be used to improve the quality of human resources. Education has an important role as a planned effort to realize a learning atmosphere and an active learning process to develop potential in learners. Doing learning activities in school is one way to improve learners' ability through the educational process in school.

Educational problems in schools have some obstacles that have an impact on the low learning outcomes of students. Obstacles that result in low student learning outcomes due to students' ability to understand learning concepts still have limitations, lack of student involvement in the learning process, the misalignment of strategies, methods, and learning models applied so far. The review results also proved that students' low learning outcomes were affected by a lack of interest in learning.

Interest in learning is a desire in students to know and understand a material they studied earnestly so that the knowledge gained is more meaningful. The low interest in learning students can be known from students' lack of attention in participating in learning activities. Students lack interest in explaining the material delivered by the teacher, the willingness to

\footnotetext{
*Email: rosnidar@mhs.unsyiah.ac.id
} 
learn is low, and students are less involved in the learning process. Efforts that can be made to solve problems in the teaching and learning process, the need to increase the effectiveness of learning models that are in accordance with the concepts and materials studied.

The results of observations at MAN 4 Aceh Besar that the learning process has carried out learning activities adapted to the application of the 2013 curriculum. There are several obstacles in the learning process, namely in determining learning models that have not been able to provide stimulus or stimulation to students to the maximum to increase the knowledge of the material learned. One of them is in physics. The results of the review in the field also proved that the average student obtained learning outcomes below the Minimum Completion Criteria score set at 75, especially in class X IPA2. The number of students who reached KKM was as many as eight $(32 \%)$, and those who had not reached Minimum Completion Criteria as many as 17 (68\%) of 25 students.

The interviews with some students also prove that several factors cause the low interest in learning physics lessons, i.e., students think physics is difficult to understand because it uses formulas and mathematical calculations. According to them, the explanation of physics is also theoretical, the language is difficult to understand, and students have difficulty understanding the concept of physics. It is influenced by the lack of practicum activities to prove the gap between theory and practice.

This is in accordance with the opinions expressed by Nurfathoanah (2017); Charli et al. (2018); Priliza et al. (2020) that the characteristics of physics have abstract object studies, and many assume that physics is difficult, filled with numbers and formulas accompanied by a monotonous and less interesting learning atmosphere so that students are afraid, lazy less interested in learning it and some learners are less active during learning activities. As a result, students' learning outcomes are unable to meet desired competencies. Apriani et al. (2020) say that physics is one part of the science that studies various objects in nature, symptoms, and phenomena that occur in nature.

Based on the problems faced by students, one of the alternative solutions in the learning process that is expected to be able to direct active students so as to affect student activity, learning outcomes, and retention of student learning outcomes towards physical learning is through the effectiveness of discovery learning models.

Discovery learning consists of six stages: (1) stimulus (stimuli), (2) problem statements (identifying problems), (3) data collection (data collection), (4) data processing (data processing), (5) verification, and (6) generalizations. Learning discovery emphasizes highlevel thinking, which is one of the abilities developed when studying physics (Damayanti et al., 2016). The Discovery learning model is one model that allows students to find information without help from teachers (In'am \& Hajar, 2016). The discovery learning model allows students to play an active role in the learning process by answering and solving problems to find concepts fully and easily rememberable (Rudibyani, 2018). This proves that the effectiveness of the discovery learning model in physics lessons has a very important role in encouraging students to be more active in the learning process.

Discovery's learning model helps students build knowledge based on existing initial knowledge. In discovery learning, concepts are not presented in the final form, but students are encouraged to identify what they want to know and seek out information themselves. The information obtained is then constructed in a final form so that the knowledge found by students becomes meaningful learning (Masril et al., 2016). The discovery learning model can be used as a model to improve students' cognitive impact on critical thinking skills (Andayani, 2020).

Based on the results of the study submitted by Ana (2018), Emylina (2018), Zauma et al. (2021) said that the application of the discovery learning model is very helpful in teacher efforts to improve student learning outcomes. This is because students who study with the discovery learning model will go through a series of stages of structured discovery learning so that students can better remember, understand, apply and analyze the material learned (Putri et al., 2017). This discovery learning model is able to increase students' interest and learning outcomes because it can increase active student engagement to get information, reduce dependence on teachers, train students to explore and utilize sources of information other than teachers.

\section{Method}

The method used in this study is the quasi method of experimentation with the design of the pretest-posttest control group. In the study method, researchers used two classes of experiment classes and control classes. The design of this study can be seen in Table 1.

Table 1. Quasi Research Design experiment

\begin{tabular}{lllll}
\hline No & Subject & Pretest & Treatment & Posttest \\
\hline 1 & Experiment & $\mathrm{O}_{1}$ & $\mathrm{X}$ & $\mathrm{O}_{2}$ \\
2 & Control & $\mathrm{O}_{3}$ & - & $\mathrm{O}_{4}$ \\
\hline
\end{tabular}

(Sugiyono, 2018)

Information: 
$\mathrm{O}_{1}=$ Pretest in an experimental class

$\mathrm{O}_{2}=$ Posttest on an experimental class

$\mathrm{O}_{3}=$ Pretest in control class

$\mathrm{O}_{4}=$ Posttest on control class

$\mathrm{X}=$ Application of Discovery Learning

The population in this study was all students of class X MAN 4 Aceh Besar, which amounted to 75 students from 3 classes. Research sample determination technique using a purposive sampling technique. Sampling is done based on the final grades of the exam held by each class in semester one, then compared to choose a class that has learning outcomes with the same grade point average. Based on the review results on the ground, the research sample taken was class X IPA2 as an experimental class and class X IPA3 as a control class. The number of students in both classes is 25 people each per class.

The instruments used in this study are questionnaires and questions to find out students' interests and learning outcomes. The data collection procedure is done by sharing students' learning interest's questionnaires and pretest questions before applying learning treatment to experimental classes and control classes. After applying the learning treatment in both classes, the final stages of sharing interest questionnaires and posttest questions were completed. The data analysis techniques in this study used the $\mathrm{N}$-gain equation and tested the average difference.

\section{Result and Discussion}

Interest in learning is the desire in the student to know and understand a material that he studied earnestly. The learning interest indicators used in this study consist of feelings of pleasure, attention, interest, willingness to learn, and student engagement. Learning interest is measured using a questionnaire consisting of pretest and posttest. The average results of students' learning interest in experimental and control classes can be seen in Table 2 .

Table 2. Results of Student Interest Analysis

\begin{tabular}{llllll}
\hline No & Class & Pretest & Posttest & N-gain & Category \\
\hline 1 & Experiment & 46 & 73 & 0.79 & High \\
2 & Control & 45 & 55 & 0.28 & Low \\
\hline
\end{tabular}

Based on the analysis of student interest data in experimental classes through the application of $\mathrm{dl}$ models, an average of $\mathrm{N}$-gain is higher than in the control class. The average $\mathrm{N}$-gain result of student learning interest in the experiment class has obtained a score of 0.79 high categories, while the control class obtained a score of 28 low categories. The average Ngain results in both classes proved that students' learning interest in the experiment class was higher than in the control class. To find out the increase in student learning interest in each indicator, it can be seen in tables 3 and 4 below.

Table 3. Results of Experimental Student Learning Interest Analysis

\begin{tabular}{llllll}
\hline No & Indicator & Pretest & Kategori & Posttest & Category \\
\hline 1 & Feelings of pleasure & 55.3 & Negative & 87.3 & Very positive \\
2 & Attention & 61.3 & Negative & 90.8 & Very positive \\
3 & Interest & 57.0 & Negative & 90.8 & Very positive \\
4 & Willingness to learn & 57.5 & Negative & 89.0 & Very positive \\
5 & Student engagement & 55.8 & Negative & 93.3 & Very positive \\
\hline
\end{tabular}

Based on the data analysis results, there was an increase in students' learning interest after applying the discovery learning model to harmonic vibrational material. The student interest learning analysis results obtained an average pretest score between 43.75-62.5 negative categories, then the posttest average score between $81.25-100$ categories was very positive. The results obtained prove that the discovery learning model is able to increase students' learning interest in each indicator. This is in accordance with research conducted by Setiawan \& Istiqomah (2018) said that the discovery learning model could foster students' learning interest because it can emphasize students' understanding and ideas so that expected learning achievements can be achieved. Nurhayani et al. (2020) said that the steps of the discovery learning model could optimize aspects of students' learning interests.

Furthermore, to find out the increase in students' learning interest in control classes before and after guessing the conventional learning model (Direct Instruction), then more clearly can be seen in table 4 .

Table 4. Results of Student Learning Interest Analysis Control Class

\begin{tabular}{llllll}
\hline No & Indicator & Pretest & Category & Posttest & Category \\
\hline 1 & Feelings of pleasure & 54.0 & Negative & 68.3 & Positive \\
2 & Attention & 57.8 & Negative & 66.0 & Positive \\
3 & Interest & 59.2 & Negative & 69.0 & Positive \\
4 & Willingness to Learn & 56.0 & Negative & 72.0 & Positive \\
5 & Student engagement & 54.7 & Negative & 68.8 & Positive \\
\hline
\end{tabular}


The results of the analysis of student learning independence in table 4 showed that after applying the conventional learning model (direct instruction), there was a positive improvement. The student's interest learning analysis results in the control class obtained an average score between 62.5-81.25 positive categories. The results proved that students' interest in control classes improved better than ever before.

Based on the results of the analysis above, it can be dreamed that the increase in students' learning interest in experimental classes using the discovery learning model is higher than the DI model. This is because the discovery learning model can involve students to solve their own problems and can instill a more creative student mindset, and have the ability to provide student learning independence. In line with research conducted by Kasmiana et al. (2020), the discovery learning model can lead students to discover their own concepts and encourage them to think and analyze themselves so that students can find concepts based on the material or data that has been provided.

To find out the difference in results between the experimental and control classes before applying the treatment, the test analysis will be different from two averages in both classes. The following are the results obtained from the test of two average student learning interests.

Table 5. Test Results Differ on Average Student Learning Interests

\begin{tabular}{lllll}
\hline No & Class & Normality & Homogeneity** & Significance*** \\
\hline 1 & Experiment & $0.090>0.05$ (normal distribution) & $0.05 \geq 0.05$ (Homogeneous) & $0.000>0.05$ (There is a significant \\
2 & Control & $0.200>0.05$ (normal distribution) & & difference) \\
\hline
\end{tabular}

Information:

*) = Kolmogorov Smirnov (normal distribution, sig $>0.05, \alpha=0.05$ )

${ }^{* *}$ ) $=$ Test of Homogeneity of Varians (Homogeneous, $\operatorname{sig} \geq 0.05, \alpha=0.05$ )

$* * *)=$ Independent Samples Test (significant, sig $<0.05, \alpha=0.05$ )

Table 5 shows the results of hypothesis test analysis in both the experimental class and the control class. Based on the analysis results, the Kolmogorov Smirnov normality test in the experimental class and control class obtained a significance value (Sig) for all data $>0.05$. It can be concluded that the study data is a normal distribution. After knowing the normality test results of normal distribution data, the next stage of conducting homogeneity tests in both classes, namely the experimental class and the control class. The homogeneity test results obtained a sig Based on a Mean value of $0.05 \geq 0.05$, so it can be concluded that the variance of experimental class data and control class is the same or homogeneous.

The results of the independent sample t-test in the experimental class and control class obtained Sig values. (2-tailed) 0.000 . If sig value. (2-tailed) $<0.05$, then there is a significant difference between the learning interests of experimental classroom students and control classes. This proves that the discovery learning model is significant to students' learning interests. This is in accordance with this research conducted by Herlily et al. (2018) said that discovery learning is a model of learning or education that requires students to find ideas and information through their own study efforts. Rahmayanti (2016) says that a person who has an interest in an object tends to pay greater attention to the object. So, if it is associated with learning, interest factors can affect a person's learning outcomes.
Assessment of students' learning outcomes in this study can be seen from the acquisition of pretest and posttest scores for each class given to students. For pretest is done at the beginning of learning with the aim to know the initial knowledge of students before doing the teaching and learning process on harmonic vibrational material in both experimental and control classes. At the same time, posttest is done at the end of learning to see how much increase the knowledge of students after the teaching and learning process takes place. To find out the average score of student learning outcomes on pretest, posttest, and $\mathrm{N}$-gain in the cognitive realm can be seen in table 6 .

Table 6. Results of Analysis of Improved Student Learning Outcomes

\begin{tabular}{llllll}
\hline No & Class & Pretest & Posttest & N-gain & Category \\
\hline 1 & Experiment & 58 & 85 & 0.61 & Medium \\
2 & Control & 56 & 72 & 0.35 & Medium
\end{tabular}

The results of the data analysis in table 6 showed that the average $\mathrm{N}$-gain of the experimental class was higher than in the control class. The average results of experimental and control classes obtained scores of 0.61 and 0.35 medium categories. Based on the results of the analysis in both classes, it can be concluded that student learning outcomes through the application of discovery learning models are more improved than the DI model. This is in accordance with research conducted by Hotang (2019) that the discovery learning model can significantly improve student learning outcomes, as evidenced by the increase of students who 
achieve learning completion. The results of Jayadiningrat et al. (2019) show that the application of the discovery learning model can improve student learning outcomes because it can make students more active and learn to be more enjoyable. The research results of Hilmi et al. (2017) showed that in experimental classes that used discovery model learning, the average student learning outcome was much more significant.

After applying the discovery learning model, hypothesis testing of learning outcomes in the cognitive realm is measured through student knowledge. The hypothesis test in this study uses an independent sample t-test because the test is carried out in two classes, namely the experimental class and the control class. The independent-sample t-test aims to find out the difference in the average learning outcome of students in both classes. Application of learning in the experimental class using discovery learning model, then DI model control class. To find out the average difference in student learning outcomes in experiment classes and control classes, it can be seen in table 7 .

Table 7. Different Test Results Average Student Learning Outcomes

\begin{tabular}{lllll}
\hline No & Class & Normality $^{*}$ & Homogeneity $^{* *}$ & Significance $^{* * *}$ \\
\hline 1 & Experiment & $0.200>0.05$ (normal distribution) & $0.013<0.05$ (Not homogeneous) & $0.000>0.05$ There is a \\
2 & Control & $0.200>0.05$ (normal distribution) & & significant difference) \\
\hline
\end{tabular}

Information:

*) = Kolmogorov Smirnov (normal distribution, sig > 0,05, $\alpha=0.05$ )

$* *)=$ Test of Homogeneity of Varians (Homogeneous, $\operatorname{sig} \geq 0.05, \alpha=0.05$ )

$* * *)=$ Independent Samples Test (significant, sig $<0.05, \alpha=0.05$ )

Table 7 shows the results of hypothesis tests in both the experimental class and the control class. Based on the analysis results proved that the Kolmogorov Smirnov normality test in the experimental class and control class obtained a significance value (Sig) for all data $>0.05$, it can be concluded that the study data is a normal distribution. The homogeneity test results obtained a sig Based on a Mean value of $0.013<0.05$, so it can be concluded that the variance of experimental class data and control classes is not the same or not homogeneous.

The results of the independent sample t-test in the experimental class and control class obtained Sig values. (2-tailed) 0.000 . If sig value. (2-tailed) $<0.05$, then there was a significant difference between the learning outcomes of experimental classroom students and control classes. This proves that the discovery learning model significantly affects students' learning outcomes in the cognitive realm. The results of the study by Jannah et al. (2021) also showed that through this discovery learning model, there was a real difference in student learning outcomes seen from the increase in average $\mathrm{N}$-gain.

This is also in accordance with research conducted by Dewi et al. (2020) said that one of the alternative learning methods that can be applied to improve student learning outcomes is the discovery learning model and the learning method of learners, this is because the discovery learning model encourages learners to develop thinking skills, problem-solving and intellectual skills in real experiences or simulations.

\section{Conclusion}

The application of the discovery learning model can increase students' learning interest in harmonic vibrational materials in MAN 4 Aceh Besar. The results of the data analysis averaged $\mathrm{N}$-gain student learning interest in the experimental class 0.79 high category and control class 0.28 low category. The results of each experimental class indicator included a very positive category while the category control class was positive. Based on the results of the analysis of both classes, it can be concluded that the average student interest in the experimental class is more increased than in the control class, especially on indicators of student engagement. The application of the discovery learning model can improve student learning outcomes in harmonious vibrational materials at MAN 4 Aceh Besar. The results of the data analysis proved that the average $\mathrm{N}$-gain in the experimental class obtained a score of 0.61 medium categories, then the control class obtained a score of 0.35 medium category. Based on the results of the test, the average of the two classes obtained significance scores of $0.000<0.05$, meaning that there was a difference in the average learning outcome of students in experimental classes and control classes. This proves that the discovery learning model's application can improve students' learning outcomes higher than the DI model in the control class.

\section{Acknowledgments}

Thank you to the leadership and teaching staff at MAN 4 Aceh Besar, who have provided service facilities 
during research. Thanks to the guidance lecturers who have been informed in completing this article.

\section{References}

Ana, N.Y. (2018). Penggunaan Model Pembelajaran Discovery Learning dalam Peningkatan Hasil Belajaran Siswa di Sekolah Dasar. Jurnal Imiah Pendidikan dan Pembelajaran, 2(1). doi:http://dx.doi.org/10.23887/jipp.v2i1.13851 [Indonesian]

Andayani, S. (2020). Development of Learning Tools Based on Discovery Learning Models Combined with Cognitive Conflict Approaches to Improve Students' Critical Thinking Ability. Jurnal Penelitian Pendidikan IPA, 6(2), 238-242. doi:https://doi.org/10.29303/jppipa.v6i2.438

Apriani, N., Doyan, A., Sridana, N., \& Susilawati, S. (2020). The validity of Physical Learning Device Based on Discovery Learning Model Assisted by Virtual Laboratory. Jurnal Penelitian Pendidikan IPA, 6(2), 132-135. doi:https://doi.org/10.29303/jppipa.v6i2.413

Charli, L., Amin, A., \& Agustina, D. (2018). Kesulitan Siswa dalam Menyelesaikan Soal Fisika pada Materi Suhu dan Kalor di Kelas X SMA ArRisalah Lubuklinggau Tahun Pelajaran 2016/2017. JOEAI:Journal of Education and Instruction, 1(1), 42-50. https://doi.org/https://doi.org/10.31539/joeai. v1i1.239 [Indonesian]

Damayanti, Q.A., Mahardika, K.I., \& Indrawati. (2016). Penerapan model discovery learning berbantuan media animasi macromedia flash disertai lks yang terintegrasi dengan multirepresentasi dalam pembelajaran fisika di SMA. Jurnal Pembelajaran Fisika, 4(4), 357-364. Retrieved from: https://jurnal.unej.ac.id/index. $\mathrm{php} / \mathrm{JPF} /$ article/view/3090 [Indonesian]

Dewi, C., Tahung, L., \& Yuris, M. (2020). Penerapan Model Pembelajaran Discovery Learning untuk Meningkatkan Hasil Belajar Fisika Materi Usaha Dan Energi Pada Peserta Didik Kelas X MIA2 SMA Negeri 3 Sampolawa Semester Genap Ta 2018/2019. Jurnal Penelitian Pendidikan Fisika, 5(1):89-99. Retrieved from http://ojs.uho.ac.id/i ndex.php/JIPFI/article/view/10482

[Indonesian]

Emylina, M. (2019). The Increase in the Results of the Study and The Activity of Learners Through The Method of Discovery Learning in Mathematics. International Journal of Educational Dynamics, 1(1), 131-135. https://doi.org/10.24036/ijeds.v1i1.26.

Herlily, V., Anhar, A., Ahda, Y., \& Sumarmin, R. (2018). Application of Learning Model Learning Guided
Discovery with Scientific Approach to Enhance Learning Competency Science Seventh Grade Students. International Journal of Progressive Sciences and Technologies, 6(2), 499-505. doi:http://dx.doi.org/10.52155/ijpsat.v6.2.274

Hilmi, N., Harjono, A., \& Soeprianto, H. (2017). Pengaruh Model Pembelajaran Discovery Dengan Pendekatan Saintifik Dan Keterampilan Proses Terhadap Hasil Belajar Fisika Peserta Didik. Jurnal Penelitian Pendidikan IPA, 3(2). doi:https://doi.org/10.29303/ippipa.v3i2.85 [Indonesian]

Hotang, L. (2019). Penerapan Model Pembelajaran Discovery Learning untuk Meningkatkan Motivasi dan Hasil Belajar Fisika Peserta Didik Kelas XI IPA 3 SMAN 6 Pekanbaru Semester Genap. Physics Education Research Journal, 1(1), 56-68.

doi:http://dx.doi.org/10.21580/perj.2019.1.1.400 $\underline{9}$

In'am, A., \& Hajar, S. (2017). Learning Geometry through Discovery Learning Using a Scientific Approach. International Journal of Instruction, 10, 55-70. https://doi.org/10.12973/iji.2017.1014a.

Jannah, M., Khaldun, I., \& Safrida, S. (2020). Application of Virtual Laboratory assisted Discovery Learning Model to Improve Science Process Skills and Learning Outcomes in Circulatory System Material. Jurnal Penelitian Pendidikan IPA, 7(1), 34-40. doi:https://doi.org/10.29303/jppipa.v7i1.470

Jayadiningrat, M., Apriawan Putra, K., \& Adistha Putra, P. (2019). Penerapan Model Pembelajaran Discovery Learning untuk Meningkatkan Aktivitas dan Hasil Belajar Siswa. Jurnal Pendidikan Kimia Undiksha, 3(2), 83-89. doi:http://dx.doi.org/10.23887/ijpk.v3i2.22699 [Indonesian]

Kasmiana, Yusrizal, \& Syukri, M. (2020). The application of guided discovery learning model to improve students concepts understanding. Journal of Physics: Conference Series, 1460, 12122. https://doi.org/10.1088/17426596/1460/1/012122

Masril., Hidayat., Darvina, Y. (2018). Penerapan Discovery Learning Berbantuan Virtual Laboratory untuk Meningkatkan Kompetensi Fisika Siswa SMA. Jurnal Penelitian Pendidikan IPA (JPIPA), 5(1):18-26. doi: https://doi.org/10.29303/ippipa.v5i1.160 [Indonesian]

Nurfathoanah, N. (2017). Implementasi Metode Pembelajaran GASING (Gampang, Asyik dan Menyenangkan) Terhadap Hasil Belajar Fisika Peserta Didik Kelas X SMA Negeri 3 
Polongbangkeng Utara. Jurnal Pendidikan Fisika, 5(3), 351-361. doi: https://doi.org/10.26618/ipf.v5i3.857.

[Indonesian]

Nurhayati., Rosnawati, R., Aminah, T. Optimization ff Guided Discovery Learning Models To Increase Students' Interest In Mathematics. Invinity Journal of Mathematics Education, 9(1):69-80. doi: https://doi.org/10.22460/infinity.v9i1.p69-80

Priliza, D.M., Lestari, N., Merta, W.I., \& Artayasa, P.I. (2020). Efektivitas Penerapan Model Discovery Learning Terhadap Hasil Belajar IPA. Jurnal Pijar MIPA, 15(2):130-134. doi: http://dx.doi.org/10.29303/jpm.v15i2.1544 [Indonesian]

Putrayasa, M.1., Syahruddin, H., \& Margunayasa, G.I. (2014). Pengaruh Model Pembelajaran Discovery Learning dan Minat Belajar Tehadap Hasil Belajar IPA Siswa. Jurnal Mimbar PGSD Universitas Pendidikan Ganesha, 2(1):1-11. doi: http://dx.doi.org/10.23887/jjpgsd.v2i1.3087 [Indonesian]

Putri, H.R., Lesmono, D.A., \& Aristya, D.P. (2017). Pengaruh Model Discovery Learning Terhadap Motivasi Belajar dan Hasil Belajar Fisika Siswa Man Bondowoso. Jurnal Pembelajaran Fisika, 6(2):173- 180.

doi: https://doi.org/10.19184/jpf.v6i2.5017 [Indonesian]

Rahmayanti, V. (2016). Pengaruh Minat Belajar Siswa dan Persepsi Atas Upaya Guru dalam Memotivasi Belajar Siswa Terhadap Prestasi Belajar Bahasa Indonesia Siswa SMP di Depok. Jurnal SAP, 1(2): 206-216. doi: http://dx.doi.org/10.30998/sap.v1i2.1027

[Indonesian]

Rudibyani, B,R. (2018). The effectiveness of discovery learning to improve critical thinking skills college student on mastery of arrhenius acid base. Jurnal Science, Engineering, Education, and Development Studies (SEEDS): Conference Series, 2(1): 41-54. doi: https://doi.org/10.20961/seeds.v2i1.24310

Setiawan, V., \& Istiqomah. 2018. Penerapan model pembelajaran discovery learning untuk meningkatkan minat dan prestasi belajar. Prosiding Seminar Nasional Etnomatnesia, Retrieved from https://jurnal.ustjogja.ac.id/inde x.php/etnomatnesia/article/view/2364 [Indonesian]

Sugiyono. (2018). Metode Penelitian Administrasi Dilegkapi dengan Metode $R$ \& $D$. Bandung: Alfabeta. [Indonesian]
Syafi'i., Marfiyanto, T., \& Rodiyah, K.S. (2018). Studi Tentang Prestasi Belajar Siswa Dalam Berbagai Aspek dan Faktor Yang Mempengaruhi. Jurnal Komunikasi Pendidikan, 2(2: 115-123. doi: https://doi.org/10.32585/jkp.v2i2.114 [Indonesian]

Zauma, F. F., Samsudi, S., \& Prasetyo, A. P. B. (2019). The Effectiveness of Discovery Learning Model using Audio-Visual Media. Journal of Primary Education, 8(7), 32-38. Retrieved from https://journal.unnes.ac.id/sju/index.php/jpe/ article/view/33827 